\title{
Validasi Metode MPM untuk Penentuan Kandungan Antioksidan dalam Sampel Herbal serta Perbandingannya dengan Metode PM, FRAP dan DPPH
}

\author{
Yefrida $^{1 *}$, Hamzar Suyani ${ }^{1}$, Hermansyah Aziz ${ }^{2}$, Mai Efdi $^{3}$ \\ ${ }^{1}$ Laboratorium Kimia Analitik, Jurusan Kimia, Fakultas Matematika dan Ilmu Pengetahuan Alam, \\ Universitas Andalas \\ ${ }^{2}$ Laboratorium Kimia Fisika, Jurusan Kimia, Fakultas Matematika dan Ilmu Pengetahuan Alam, \\ Universitas Andalas \\ ${ }^{3}$ Laboratorium Kimia Organik Bahan Alam, Jurusan Kimia, Fakultas Matematika dan Ilmu \\ Pengetahuan Alam, Universitas Andalas
}

\author{
Corresponding Author: \\ Yefrida \\ yefanwar@gmail.com \\ Received: January 2020 \\ Accepted: March 2020 \\ Published: March 2020 \\ CYefrida et al. This is an \\ open-access article \\ distributed under the terms \\ of the Creative Commons \\ Attribution License, which \\ permits unrestricted use, \\ distribution, and \\ reproduction in any \\ medium, provided the \\ original author and source \\ are credited.
}

\begin{abstract}
The Modified Phenanthroline Method (MPM) has been validated for determination of antioxidant content in herb samples. Validation was done using Relative Standard Deviation (RSD) and percentage of recovery. The RSD and percentage of recovery for herb samples are $3.13 \%$ and $98.6 \%$, respectively. Based on these values, MPM method is valid for determining antioxidant content in herb samples. T test shows no significant differences of antioxidant content using any of these methods, MPM, PM, FRAP or $\mathrm{DPPH}$, at a 95\% confidence level. MPM method shows a very strong correlation with PM and FRAP method. While with DPPH and TPC shows is strong.
\end{abstract}

Keywords: MPM method, antioxidant content, method comparison, method correlation

\section{Pendahuluan}

Atom atau molekul yang mengandung satu atau lebih elektron yang tidak berpasangan disebut sebagai radikal bebas. Radikal bebas ini biasanya berupa spesies oksigen atau nitrogen reaktif. Contoh radikal bebas yaitu radikal hidroksil, radikal hidroperoksil, radikal lipid, radikal nitrogen oksida, radikal kation nitrosil dan lain-lain) ${ }^{[1]}$. Radikal bebas dapat dihasilkan dari sumber endogen maupun eksogen. Sumber endogen misalnya berasal dari respirasi mitokondria yang menghasilkan radikal superoksida anion, otooksidasi molekul seperti haemoglobin, mioglobin dan lain lain yang menghasilkan radikal superoksida[2]. Radikal bebas yang berasal dari sumber eksogen misalnya pernapasan dengan menggunakan udara tercemar, partikel anorganik dalam udara, asap dari rokok tembakau, pelarut organik yang dipakai di industri, obat-obatan seperti obat kanker, penghilang rasa sakit dan lain-lain[3]-[5]. Radikal bebas dapat merusak semua biomolekul seperti lipid, potein, karbohidrat dan asam nukleat. Lipid merupakan target utama kerusakan oksidatif yang dipicu oleh radikal bebas. Lipid peroksidasi menyebabkan kerusakan membran sel dengan merobah fluiditas dan permiabelitas membran. Lipid peroksidasi dimediasi oleh 
radikal bebas melalui sederetan reaksi rantai yang melibatkan inisiasi, propagasi dan terminasi. Radikal bebas yang dapat menginisiasi lipid peroksidasi meliputi radikal hidroksil (paling reaktif), radikal peroksil dan peroksinitrit. Ion-ion logam seperti ion $\mathrm{Cu}^{+}$dan $\mathrm{Fe}^{2+}$ bisa berperan sebagai katalis dalam rantai inisiasi ini[ ${ }^{[6]}$.

Radikal bebas dapat menyebabkan sejumlah penyakit seperti kanker[7], jantung[8], kelainan syaraf ${ }^{[9]}$, Alzheimer' $\mathbf{s}^{[10]}$, Parkinson' ${ }^{[11]}$ dan lainlain. Agar tubuh dari terlindung dari pengaruh buruk radikal bebas maka harus mengkonsumsi antioksidan baik yang berasal dari makanan maupun dari suplemen. Makanan yang mengandung antioksidan dipercaya dapat mencegah sejumlah penyakit berdasarkan bukti-bukti yang ada. Para peneliti menyatakan bahwa kombinasi antioksidan lebih baik dari antioksidan tunggal dan lebih efektif untuk perlindungan jangka panjang. Antioksidan dapat meningkatkan kualitas hidup manusia dengan cara mencegah atau menunda timbulnya penyakit-penyakit degeratif, disamping itu juga dapat mengurangi biaya yang dibutuhkan untuk menjaga kesehatan[12].

Masyarakat sejak zaman dahulu sudah menggunakan ekstraktumbuhan sebagai bahan obat disebabkan karena kaya akan senyawa bioaktif seperti alkaloid, flavonoid, senyawa polifenol dan lain-lain ${ }^{[13],[14]}$. Salah satu senyawa metabolit sekunder yang ada pada tanaman adalah senyawa-senyawa yang bersifat sebagai antioksidan. Berdasarkan hal ini, World Health Organization (WHO) mempomosikan penggunaan bahan-bahan ini untuk pengobatan. Disamping itu mereka juga memberikan aturan tentang kualitas, keamanan dan keefisienan obat-obat herbal ini. Fokus perhatian dunia terletak pada produksi yang berkelanjutan dan keefisienan herbal ini[15].

Penentuan kandungan antioksidan dalam herbal telah banyak dilakukan. Jaradat et al $(2017)^{[16]}$ telah meneliti kandungan antioksidan dalam herbal Ononis pubescens L. Peneliti menemukan bahwa fraksi aseton dari tumbuhan ini mempunyai kandungan antioksidan yang tinggi dibandingkan dengan fraksi n-heksan dan metanol. Vyas et al., (2010)[17] menentukan kandungan antioksidan dalam jambu biji. Ojezele et al (2016) ${ }^{[18]}$ meneliti kandungan antioksidan dari ekstrak etanol dan air dari daun, biji dan buah tanaman Annona muricata Linn. Penentuan kandungan antioksidan pada penelitian tersebut dilakukan menggunakan metode DPPH. Metode DPPH merupakan metode yang paling umum digunakan untuk penentuan kandungan antioksidan dalam sampel alam. Hal ini disebabkan oleh karena metode ini praktis dan sederhana.

Pada penelitian ini didunakan metode Modified Phenanthroline Method (MPM) untuk penentuan kandungan antioksidan dalam sampel herbal, yang merupakan modifikasi dari metode Phenanthroline Method (PM). Metode ini telah divalidasi untuk penentuan kandungan antioksidan dalam buah dan sayur. Metode ini merupakan metode yang valid, teliti dan akurat ${ }^{[19]}$. Disamping itu juga dilakukan perbandingan metode dengan metode PM, FRAP dan DPPH serta korelasi antar metode tersebut.

\section{Metode Penelitian}

\section{Bahan kimia}

Bahan yang digunakan dalam penelitian ini adalah asam askorbat (merck), asam galat (Merck), troloks (Sigma), $\mathrm{FeSO}_{4} \cdot 6 \mathrm{H}_{2} \mathrm{O}$ (Merck), $\mathrm{FeCl}_{3} \cdot 6 \mathrm{H}_{2} \mathrm{O}$ (Merck), 1.10-fenantrolin klorida monohidrat (Sigma), TPTZ (Sigma), asam asetat (Merck), natrium asetat (Merck), DPPH (Sigma), reagen Folin-Ciocalteau (Sigma), $\mathrm{Na}_{2} \mathrm{CO}_{3}$ (Merck), metanol (Merck) dan akuades.

\section{Peralatan}

Alat-alat yang digunakan dalam penelitian ini adalah spektrofotometer UV-Vis (PD-303 S Spectrophotometer), neraca analitis, oven dan alat-alat gelas laboratorium.

\section{Sampel}

Sampel yang digunakan pada penelitian ini adalah daun alpukat (Persea americana leaf), daun jambu biji (Psidium guajava leaf), daun 
sirsak (Annona muricata leaf), daun sirih (Piper betle leaf), daun seledri (Apium graveolens), daun rambutan (Nephelium lappaceum L. leaf), daun sereh (Cymbopogon citratus leaf), daun srikaya (Annona squamosa leaf), daun suruhan (Peperomia pellucida L. leaf) dan daun kembang sepatu (Hibiscus rosa-sinensis L. leaf). Semua sampel yang digunakan dibeli dari pasar tradisional di Kota Padang, Sumatera Barat, Indonesia.

\section{Prosedur penelitian}

\section{Perlakuan terhadap sampel}

Sampel dibersihkan dan dipotong kecil-kecil lalu ditimbang sebanyak \pm 2 g. Sampel dimaserasi dengan menggunakan pelarut metanol atau air selama 2 jam. Campuran disaring dengan menggunakan kertas saring. Filtrat yang didapatkan digunakan untuk penentuan kandungan antioksidan.

\section{Kurva kalibrasi standar}

Kurva kalibrasi standar dibuat dengan menggunakan larutan $\mathrm{FeSO}_{4} .7 \mathrm{H}_{2} \mathrm{O}(0.05-0.5$ $\mathrm{mM}$ ) untuk metode MPM, PM and FRAP, sementara untuk penentuan kandungan fenolik total digunakan larutan asam galat $(50-300)$ $\mathrm{mg} / \mathrm{L}$.

\section{Penentuan kandungan antioksidan dalam sampel dengan metode MPM}

Ke dalam tabung reaksi dimasukkan $1 \mathrm{~mL}$ fenantrolin $0.2 \%$ kemudian ditambahkan $1 \mathrm{~mL}$ $\mathrm{FeCl}_{3} 0.1 \%, 2 \mathrm{~mL}$ akuades dan $1 \mathrm{~mL}$ ekstrak sampel. Larutan dikocok, kemudian didiamkan selama 20 menit. Absorbans diukur pada panjang gelombang $510 \mathrm{~nm}$ dengan spektrofotometer UV/Vis. Analisis ini dilakukan dengan 3 kali ulangan[19].

\section{Penentuan kandungan antioksidan dengan metode PM}

Ke dalam labu ukur $10 \mathrm{~mL}$ dimasukkan $0.5 \mathrm{~mL}$ fenantrolin $0.5 \%$ kemudian ditambahkan $1 \mathrm{~mL}$ $\mathrm{FeCl}_{3} 0.2 \%$ dan $0.6 \mathrm{~mL}$ ekstrak sampel. Volume larutan dicukupkan hingga $10 \mathrm{~mL}$ dengan metanol. Larutan dikocok, kemudian didiamkan selama 20 menit. Absorbans diukur pada panjang gelombang $510 \mathrm{~nm}$ dengan spektrofotometer UV/Vis. Analisis ini dilakukan dengan 3 kali ulangan[20].

\section{Penentuan kandungan antioksidan dengan metode FRAP}

Ke dalam labu ukur $10 \mathrm{~mL}$ dimasukkan $2 \mathrm{~mL}$ reagen FRAP $(2.5 \mathrm{~mL} \mathrm{FeCl} 320 \mathrm{mM}+2.5 \mathrm{~mL}$ TPTZ $10 \mathrm{mM}$ dilarutkan dalam $25 \mathrm{~mL}$ bufer asetat $\mathrm{pH}$ 3.65) kemudian ditambahkan $0.3 \mathrm{~mL}$ ekstrak sampel. Volume larutan dicukupkan hingga $10 \mathrm{~mL}$ dengan bufer. Larutan dikocok kemudian didiamkan selama 10 menit. Absorbans diukur pada panjang gelombang $510 \mathrm{~nm}$ dengan spektrofotometer UV/Vis. Analisis ini dilakukan dengan 3 kali ulangan[20].

\section{Penentuan kandungan antioksidan dengan metode DPPH}

Ke dalam tabung reaksi dimasukkan $1.0 \mathrm{~mL}$ ekstrak sampel lalu ditambahkan $0.5 \mathrm{~mL}$ metanol dan $1.5 \mathrm{~mL}$ DPPH $0.3 \mathrm{mM}$. Larutan dikocok, kemudian didiamkan selama 15 menit. Absorbans diukur pada panjang gelombang $510 \mathrm{~nm}$ dengan spektrofotometer UV/Vis. Analisis ini dilakukan dengan 3 kali ulangan ${ }^{[21]}$.

\section{Penentuan TPC}

Ke dalam tabung reaksi ditambahkan $4 \mathrm{~mL}$ $\mathrm{Na}_{2} \mathrm{CO}_{3} 2 \%$ kemudian ditambahkan $0.2 \mathrm{~mL}$ ekstrak sampel. Lalu ditambahkan $0.2 \mathrm{~mL}$ reagen Folin-Ciocalteau : metanol (1:1). Larutan dikocok dan didiamkan selama 30 menit. Absorbans diukur pada panjang gelombang $750 \mathrm{~nm}$ dengan spektrofotometer UV/Vis. Analisis ini dilakukan dengan 3 kali ulangan[20].

Untuk metode MPM, PM dan FRAP, kandungan antioksidan dinyatakan sebagai mmol Fe/g DW, sedangkan untuk metode DPPH dinyatakan sebagai $\mu \mathrm{mol}$ AA/g DW.

\section{Analisis statistik}

Analisis statistik deskriptif dilakukan dengan menggunakan Microsoft Excell. Data 
dinyatakan sebagai rata-rata \pm standard deviasi yang didapatkan dari 3 kali ulangan.

\section{Hasil dan Diskusi}

\section{Validasi metode}

\section{Nilai RSD}

Nilai RSD ekstrak metanol herbal yang didapatkan untuk metode MPM dan PM adalah $3.13 \pm 1.50 \%$ dan $3.44 \pm 1.07 \%$, berturutturut (Tabel 1). Berdasarkan uji $\mathrm{t}$ didapatkan nilai $\mathrm{p}(0.491)>\alpha(0.05)$, berarti tidak ada perbedaan nyata antara nilai RSD herbal antara metode MPM dan PM.

Nilai RSD untuk sampel buah, sayur dan herbal dengan menggunakan metanol atau akuades sebagai pelarut adalah $<5 \%$. Nilai ini didapatkan untuk metode MPM maupun PM. Nilai RSD ini memenuhi persyaratan nilai RSD yang diperbolehkan untuk analisis yaitu kecil dari $6 \%{ }^{[22]}$.
Peneliti-peneliti lain mendapatkan nilai RSD yang berbeda-beda. Szydłowska-Czerniak et al., $(2008)^{[20]}$ menggunakan metode fenantrolin untuk menentukan kandungan antioksidan dalam sampel minyak sayur yang diekstrak dengan aseton dan metanol, nilai RSD yang didapatkan adalah sebesar $(0.8-4.6 \%)$ dan (0.9 - 4.9\%), berturut-turut. Pengujian dengan metode FRAP didapatkan nilai RSD sebesar $(0.7-4.0 \%)$ dan $(0.6-4.0 \%)$ untuk pelarut aseton dan metanol, berturut-turut. Szydłowska-Czerniak et al., (2008)[20] mendapatkan nilai RSD sebesar (0.49 - 4.37\%) dan $(0.56-3.71 \%)$ untuk penentuan kandungan antioksidan dalam sampel rapeseed dan olive oil dengan menggunakan metode ORAC dan FRAP, berturut-turut. Szydłowska-Czerniak et al., (2013) dengan menggunakan metode AgNP mendapatkan nilai 1.4 - 4.4\%) sedangkan dengan menggunakan metode FRAP modifikasi, DPPH dan FC didapatkan nilai 1.0 - 4.4\%, 0.7 - 2.1\% dan 0.8 - 3.6\%, berturut turut. Nilai RSD yang didapatkan hampir sama dengan yang didapatkan pada penelitian ini yaitu $<5 \%$.

Tabel 1. Nilai RSD sampel herbal

\begin{tabular}{lllc}
\hline \multirow{2}{*}{ No } & \multicolumn{1}{c}{ Sampel } & \multicolumn{2}{c}{ RSD (\%) } \\
\cline { 3 - 4 } & & MPM & PM \\
\hline 1 & Daun Alpukat (Persea americana) & 2,32 & 2,60 \\
2 & Daun Jambu Biji (Psidium guajava) & 0,00 & 2,95 \\
3 & Daun Sirsak (Annona muricata) & 3,48 & 3,45 \\
4 & Daun Sirih (Piper betle) & 4,89 & 3,60 \\
5 & Daun Seledri (Apium graveolens) & 3,69 & 3,29 \\
6 & Daun Rambutan (Nephelium lappaceum L.) & 1,92 & 4,44 \\
7 & Daun Sereh (Cymbopogon citratus) & 3,81 & 3,54 \\
8 & Daun Srikaya (Annona squamosa) & 2,25 & 4,45 \\
9 & Daun Suruhan (Peperomia pellucida L.) & 4,36 & 1,18 \\
10 & $\begin{array}{l}\text { Daun Kembang Sepatu (Hibiscus rosa-sinensis } \\
\text { L.). }\end{array}$ & 4,55 & 4,90 \\
\hline
\end{tabular}


Tabel 2. Nilai perolehan kembali sampel herbal

\begin{tabular}{llcc}
\hline \multirow{2}{*}{ No } & \multicolumn{1}{c}{ Sampel } & \multicolumn{2}{c}{ Perolehan kembali (\%) } \\
\cline { 3 - 4 } & & MPM & PM \\
\hline 1 & Daun Alpukat (Persea americana) & 99 & 93 \\
2 & Daun Jambu Biji (Psidium guajava) & 94 & 94 \\
3 & Daun Sirsak (Annona muricata) & 102 & 94 \\
4 & Daun Sirih (Piper betle) & 93 & 97 \\
5 & Daun Seledri (Apium graveolens) & 93 & 98 \\
6 & Daun Rambutan (Nephelium lappaceum L.) & 107 & 99 \\
7 & Daun Sereh (Cymbopogon citratus) & 93 & 94 \\
8 & Daun Srikaya (Annona squamosa) & 107 & 109 \\
9 & Daun Suruhan (Peperomia pellucida L.) & 92 & 99 \\
\multirow{2}{*}{10} & Daun Kembang Sepatu (Hibiscus rosa-sinensis & 106 & 102 \\
\hline
\end{tabular}

\section{Nilai perolehan kembali}

Nilai perolehan kembali rata-rata ekstrak metanol sampel herbal yang didapatkan untuk metode MPM dan PM adalah $98.6 \pm 6.4 \%$ dan $97.6 \pm 4.9 \%$, berturut-turut (Tabel 2). Berdasarkan uji $t$ untuk metode MPM dan PM didapatkan nilai $\mathrm{p}(0.04)<\alpha(0.05)$, berarti terdapat perbedaan nyata antara nilai perolehan kembali sayur antara metode MPM dan PM.

Nilai perolehan kembali untuk sampel buah, sayur dan herbal dengan menggunakan metanol sebagai pelarut adalah $100 \pm 10 \%$. Nilai ini didapatkan untuk metode MPM maupun PM. Nilai perolehan kembali ini memenuhi persyaratan nilai perolehan kembali yang diperbolehkan untuk analisis yaitu sebesar 90 $108 \%{ }^{[22]}$. Kandungan antioksidan total dalam ekstrak metanol sampel herbal

Kandungan antioksidan total dalam ekstrak metanol sampel herbal ditentukan dengan menggunakan metode MPM, PM, FRAP dan DPPH. Hal ini bertujuan untuk melihat perbandingan hasil yang didapatkan dengan menggunakan metode MPM yang masih baru dengan metode PM, FRAP dan DPPH yang sudah umum digunakan sebagai metode penentuan kandungan antioksidan total dalam sampel. Metode MPM, PM dan FRAP merupakan metode yang berdasarkan pada reduksi besi dimana antioksidan akan mengalami reaksi oksidasi dengan adanya $\mathrm{FeCl}_{3}$ sedangkan $\mathrm{FeCl}_{3}$ akan mengalami reaksi reduksi menghasilkan ion $\mathrm{Fe}^{2+}$. Ion yang terbentuk ini akan membentuk senyawa kompleks dengan reagen pengompleks yang digunakan dan serapannya diukurdengan menggunakan alat spektrofotometer. Metode DPPH merupakan metode penentuan antioksidan total dengan menggunakan reagen DPPH yang berfungsi sebagai penangkap radikal bebas.

\section{Perbandingan kandungan antioksidan antara metode MPM dengan PM}

Uji t dilakukan dengan menggunakan data pada Tabel 3. Berdasarkan uji t didapatkan nilai $\mathrm{p}(0.37)>\alpha$ (0.05), berarti kandungan antioksidan total dalam sampel herbal yang diekstrak dengan pelarut metanol, yang 
ditentukan dengan metode MPM dan PM tidak berbeda nyata. Korelasi (r) antara metode MPM dan PM dapat dilihat pada Gambar 1. Nilai $\mathrm{R}^{2}$ yang didapatkan 0.9501 dan nilai $\mathrm{r}=0.9747$. Nilai $\mathrm{r}$ ini menyatakan bahwa terdapat korelasi yang sangat kuat antara metode MPM dan PM dalam penentuan kandungan antioksidan total dalam sampel herbal yang diekstrak dengan pelarut metanol.

\section{Perbandingan kandungan antioksidan antara metode MPM dengan FRAP}

Uji $t$ dilakukan dengan menggunakan data pada Tabel 3. Berdasarkan uji t didapatkan nilai p (0.25) > nilai $\alpha(0.05)$, berarti kandungan antioksidan total dalam ekstrak metanol herbal yang ditentukan dengan metode MPM dan FRAP tidak berbeda nyata. Korelasi (r) antara metode MPM dan FRAP dapat dilihat pada Gambar 2. Nilai $R^{2}$ yang didapatkan 0.9891 dan nilai $\mathrm{r}=0.9945$. Nilai $\mathrm{r}$ ini menyatakan bahwa terdapat korelasi yang sangat kuat antara metode MPM dan PM dalam penentuan kandungan antioksidan total dalam sampel herbal dengan pelarut methanol.

\section{Perbandingan kandungan antioksidan antara metode MPM dengan DPPH}

Uji $\mathrm{t}$ dilakukan dengan menggunakan data pada Tabel 3. Berdasarkan uji t didapatkan nilai p (0.129) > nilai $\alpha(0.05)$, berarti kandungan antioksidan total yang ditentukan dengan metode MPM dan DPPH dengan pelarut metanol tidak berbeda nyata. Korelasi (r) antara metode MPM dan DPPH dapat dilihat pada Gambar 3. Nilai $R^{2}$ yang didapatkan 0.6504 dengan nilai $\mathrm{r}=0.8065$. Nilai $\mathrm{r}$ ini menyatakan bahwa terdapat korelasi yang kuat antara metode MPM dan DPPH dalam penentuan kandungan antioksidan total dalam sampel herbal dengan pelarut metanol.

Tabel 3. Kandungan antioksidan total ekstrak metanol sampel herbal dengan metode MPM, PM, FRAP dan DPPH

\begin{tabular}{|c|c|c|c|c|c|}
\hline \multirow{3}{*}{ No } & \multirow{3}{*}{ Sampel } & \multicolumn{4}{|c|}{ Kandungan antioksidan } \\
\hline & & \multicolumn{3}{|c|}{$(\mu \mathrm{mol} \mathrm{Fe} / \mathrm{g} \mathrm{DW})($ mean $\pm \mathrm{SD})$} & \multirow{2}{*}{$\begin{array}{c}\begin{array}{c}(\mu \mathrm{mol} \mathrm{AA} / \mathrm{g} \\
\text { DW) (mean } \\
\pm \mathrm{SD})\end{array} \\
\text { DPPH }\end{array}$} \\
\hline & & MPM & PM & FRAP & \\
\hline 1 & Daun Alpukat (Persea americana) & $450.60 \pm 15.0$ & $512.70 \pm 10.47$ & $614.49 \pm 14.14$ & $63.38 \pm 1.30$ \\
\hline 2 & Daun Jambu Biji (Psidium guajava) & $49.80 \pm 0.00$ & $79.40 \pm 5,02$ & $88.95 \pm 1.66$ & $6.85 \pm 0.06$ \\
\hline 3 & Daun Sirsak (Annona muricata) & $25.00 \pm 0.80$ & $16.90 \pm 0.78$ & $19.94 \pm 1.06$ & $6.19 \pm 0.09$ \\
\hline 4 & Daun Sirih (Piper betle) & $49.20 \pm 0.84$ & $130.90 \pm 10.07$ & $103.68 \pm 1.23$ & $39.22 \pm 1.62$ \\
\hline 5 & Daun Seledri (Apium graveolens) & $130.75 \pm 3,20$ & $155.17 \pm 1.89$ & $235.00 \pm 8.00$ & $69.33 \pm 0.58$ \\
\hline 6 & $\begin{array}{l}\text { Daun Rambutan (Nephelium lappaceum } \\
\text { L.) }\end{array}$ & $436.67 \pm 16.74$ & $416.00 \pm 19.00$ & $537.33 \pm 2.73$ & $61.00 \pm 1.00$ \\
\hline 7 & Daun Sereh (Cymbopogon citratus) & $33.60 \pm 0.95$ & $43.50 \pm 1.22$ & $69.47 \pm 1.91$ & $21.74 \pm 0.23$ \\
\hline 8 & Daun Srikaya (Annona squamosa) & $58.10 \pm 0.00$ & $79.70 \pm 2.73$ & $126.54 \pm 3.89$ & $18.57 \pm 0.00$ \\
\hline 9 & Daun Suruhan (Peperomia pellucida L.) & $79.00 \pm 0.00$ & $173.00 \pm 0.30$ & $150.83 \pm 1.42$ & $25.67 \pm 0.58$ \\
\hline 10 & $\begin{array}{l}\text { Daun Kembang Sepatu (Hibiscus rosa- } \\
\text { sinensis L.). }\end{array}$ & $36.00 \pm 1.00$ & $49.67 \pm 1.53$ & $47.33 \pm 0.17$ & - \\
\hline
\end{tabular}




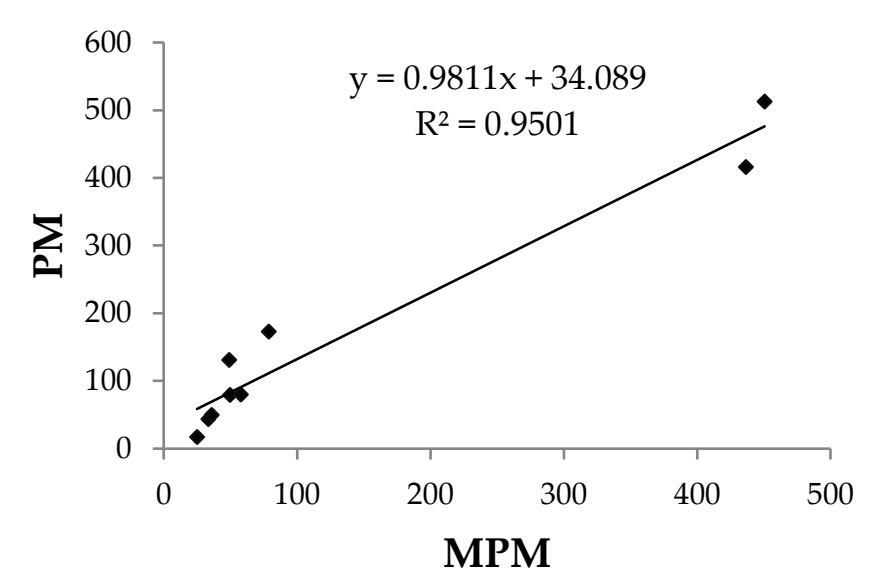

Gambar 1. Korelasi antara metode MPM dan PM.

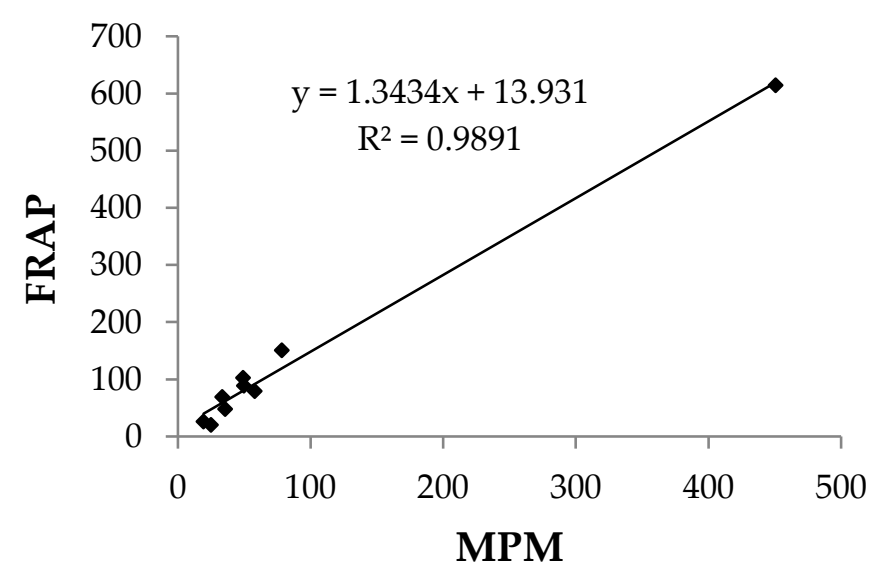

Gambar 2. Korelasi antara metode MPM dan FRAP.

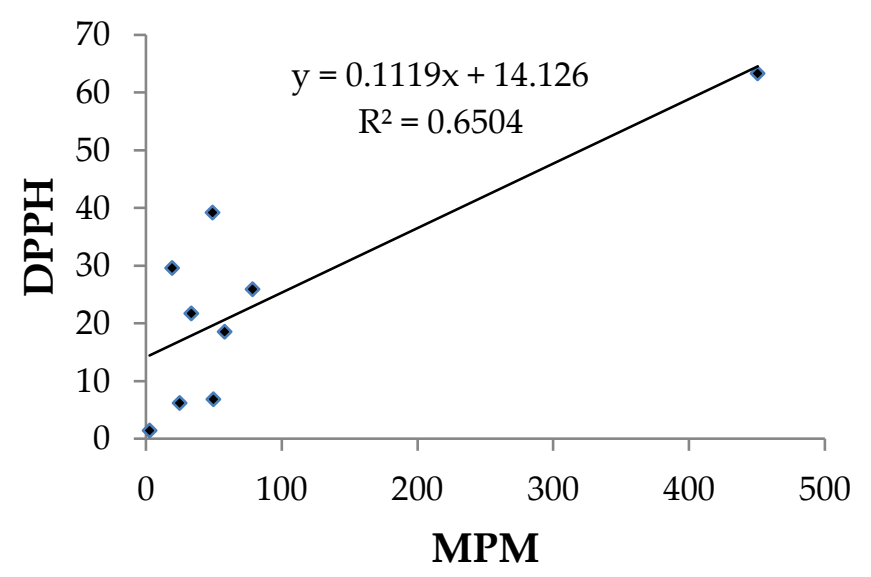

Gambar 3. Korelasi antara metode MPM dan DPPH. 
Perbandingan hasil penentuan kandungan antioksidan yang digunakan dengan beberapa metode dapat dilihat pada Tabel 4. Berdasarkan data ini dapat diambil kesimpulan bahwa penentuan kandungan antioksidan denagn menggunakanmetode MPM, PM, FRAP dan DPPH memberikan hasil yang tidak berbeda nyata dengan korelasi yang sangat kuat dan kuat.

\section{TPC dalam ekstrak metanol sampel herbal}

Kandungan TPC dalam ekstrak metanol sampel herbal, dapat dilihat pada Tabel 5. Kandungan TPC yang didapatkan berkisar antara (5.25 \pm $0.17-121.16 \pm 1.30) \mathrm{mg}$ AG/g DW. Kandungan TPC terbesar untuk ekstrak metanol didapatkan pada daun alpukat, sedangkan yang terendah didapatkan pada daun sirsak.

Tabel 4. Ringkasan nilai hasil uji t dan korelasi antara metode MPM dengan metode PM, FRAP dan DPPH pada ekstrak metanol sampel herbal

\begin{tabular}{llcc}
\hline No & Perbandingan Metode & Hasil Uji T & Korelasi \\
\hline 1 & MPM - PM & Tidak berbeda nyata & Sangat kuat \\
2 & MPM - FRAP & Tidak berbeda nyata & Sangat kuat \\
3 & MPM - DPPH & Tidak berbeda nyata & Kuat \\
\hline
\end{tabular}

Tabel 5. TPC dalam ekstrak sampel herbal

\begin{tabular}{llc}
\hline No & \multicolumn{1}{c}{ Sampel } & $\begin{array}{c}\text { Perolehan kembali (\%) } \\
\text { MPM } \\
\text { PM }\end{array}$ \\
\hline 1 & Daun Alpukat (Persea americana) & $121.16 \pm 1.30$ \\
2 & Daun Jambu Biji (Psidium guajava) & $11.54 \pm 1.30$ \\
3 & Daun Sirsak (Annona muricata) & $5.25 \pm 0.17$ \\
4 & Daun Sirih (Piper betle) & $29.88 \pm 7.90$ \\
5 & Daun Seledri (Apium graveolens) & $60.83 \pm 1.30$ \\
6 & Daun Rambutan (Nephelium lappaceum L.) & $61.07 \pm 0.53$ \\
7 & Daun Sereh (Cymbopogon citratus) & $18.60 \pm 5.60$ \\
8 & Daun Srikaya (Annona squamosa) & $22.62 \pm 0.40$ \\
9 & Daun Suruhan (Peperomia pellucida L.) & $27.21 \pm 0.13$ \\
\multirow{2}{*}{10} & $\begin{array}{l}\text { Daun Kembang Sepatu (Hibiscus } \\
\text { rosa-sinensis }\end{array}$ & $5.62 \pm 0.06$ \\
\hline
\end{tabular}


Untuk menentukan korelasi antara metode MPM dan TPC pada sampel herbal digunakan data pada Tabel 3 dan Tabel 5. Korelasi antara metode MPM dan TPC untuk ekstrak metanol sampel sayur dapat dilihat pada Gambar 4 di bawah ini. Nilai $R^{2}$ yang didapatkan 0.6718 dengan nilai $r=0.8193$. Nilai $r$ ini menyatakan bahwa terdapat korelasi yang kuat antara metode MPM dan TPC. Hal ini menunjukkan bahwa kandungan antioksidan dalam sampel herbal ini didominasi oleh senyawa-senyawa fenolik.

Korelasi antar metode penentuan kandungan antioksidan yang digunakan dengan TPC dapat dilihat pada Tabel 6. Nilai korelasi yang didapatkan berkisar antara (0.8193 - 0.9746) yang menunjukkan korelasi yang kuat dan sangat kuat antara TPC dengan metode MPM, PM, FRAP dan DPPH. Hal ini menyatakan bahwa kandungan antioksidan di dalam sampel yang ditentukan dengan metodemetode tersebut didominasi oleh senyawa fenolik. Butsat dan Siriamornpun (2016) juga mendapatkan korelasi yang kuat dan sangat kuat antara TPC dengan metode DPPH, ABTS dan FRAP yang nilainya $0.805 ; 0.873$ dan 0.975 , berturut-turut. Szydłowska-Czerniak et al., (2008) mendapatkan nilai korelasi antara metode FRAP dan TPC sebesar 0.9047 dan 0.8409 untuk sampel rapeseed dan olive oil, berturut-turut. Korelasi yang didapatkan antara metode tersebut dengan TPC juga termasuk korelasi yang kuat dan sangat kuat ${ }^{[23]}$.

Tabel 6. Nilai korelasi antara kandungan antioksidan beberapa metode dengan TPC dalam ekstrak metanol sampel herbal

\begin{tabular}{lll}
\hline No & Perbandingan Metode & Korelasi \\
\hline 1 & MPM -TPC & 0.8193 \\
2 & PM - TPC & 0.9152 \\
3 & FRAP - TPC & 0.9746 \\
4 & DPPH - TPC & 0.9252 \\
\hline
\end{tabular}

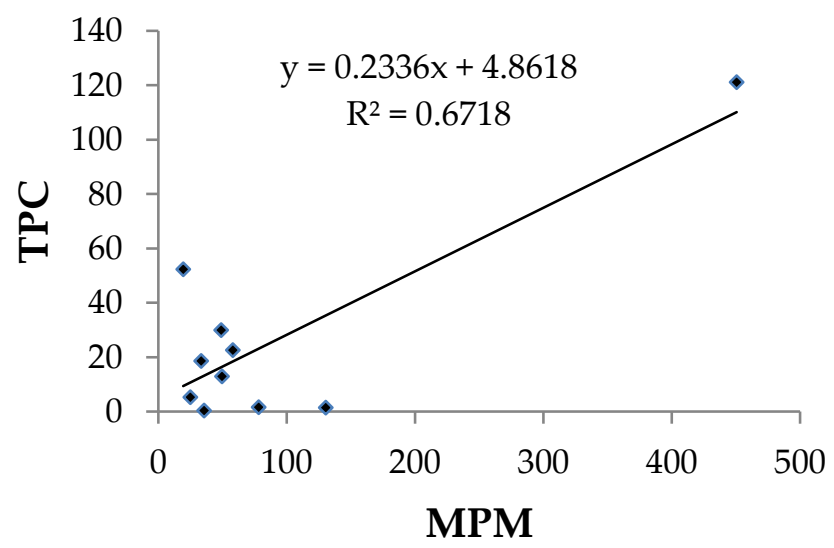

Gambar 4. Korelasi antara metode MPM dan TPC. 
TPC yang didapatkan dalam sampel herbal pada penelitian ini maupun yang dilakukan oleh peneliti lain mempunyai nilai yang bervariasi. Hal ini dapat disebabkan oleh beberapa faktor yang menentukan dalam proses ekstraksi seperti jenis pelarut dan konsentrasinya, waktu dan suhu ekstraksi serta jenis dan ukuran sampel yang digunakan [24],[25].

\section{Kesimpulan}

Berdasarkan penelitian yang telah dilakukan dapat diambil kesimpulan bahwa metode MPM merupakan metode yang valid untuk penentuan kandungan antioksidan total dalam sampel herbal. Kandungan antioksidan total sampel herbal yang diuji dengan metode MPM tidak berbeda nyata dengan kandungan antioksidan total sampel herbal yang diuji dengan metode PM, FRAP dan DPPH. Korelasi antara metode MPM dengan metode PM, FRAP dan DPPH merupakan korelasi yang sangat kuat sedangkan dengan TPC merupakan korelasi yang kuat.

\section{Ucapan Terima Kasih}

Peneliti mengucapkan terima kasih kepada Fakultas Matematika dan Ilmu Pengetahuan Alam Universitas Andalas yang telah memberikan bantuan dana penelitian melalui kontrak nomor 02/UN.16.03.D/PP/FMIPA/2019 sehingga penelitian ini bisa terlaksana dengan baik.

\section{Daftar Pustaka}

1. Kunwar, A. \& Priyadarsini, K. I., Free radicals, oxidative stress and importance of antioxidants in human health. $J$ Med Allied Sci, 1(2): 53-60 (2011).

2. Powers, S. K. \& Jackson, M. J., Exerciseinduced oxidative stress: Cellular mechanisms and impact on muscle force production. Physiol. Rev., 88(4): 1243-1276 (2008).

3. Li, X. Y., Gilmour, P. S., Donaldson, K. \& MacNee, W., Free radical activity and proinflammatory effects of particulate air pollution (PM10) in vivo and in vitro. Thorax, 51(12): 1216-1222 (1996).

4. P., L. J., Xi, L., Shengfeng, W., M.Y., L. M., D., B. G., R., M. M., R., C. F., et al., Reducing personal exposure to particulate air pollution improves cardiovascular health in patients with coronary heart disease. Environ. Health Perspect., 120(3): 367-372 (2012).

5. Ho, H., Cheng, M. \& Chiu, D. T., Glucose6-phosphate dehydrogenase-from oxidative stress to cellular functions and degenerative diseases. Redox Rep., 12(3): 109-118 (2007).

6. $\mathrm{Xu}, \mathrm{Y} ., \mathrm{Gu}, \mathrm{Y}$. \& Qian, S. Y., An advanced electron spin resonance (ESR) spintrapping and LC/(ESR)/MS technique for the study of lipid peroxidation. Int. J. Mol. Sci., 13(11): 14648-14666 (2012).

7. Kinnula, V. L. \& Crapo, J. D., Superoxide dismutases in malignant cells and human tumors. Free Radic. Biol. Med., 36(6): 718744 (2004).

8. Singh, U. \& Jialal, I., Oxidative stress and atherosclerosis. Pathophysiology, 13(3): 129142 (2006).

9. Sas, K., Robotka, H., Toldi, J. \& Vécsei, L., Mitochondria, metabolic disturbances, oxidative stress and the kynurenine system, with focus on neurodegenerative disorders. J. Neurol. Sci., 257(1-2): 221-239 (2007).

10. Smith, M. A., Rottkamp, C. A., Nunomura, A., Raina, A. K. \& Perry, G., Oxidative stress in Alzheimer's disease. Biochim. Biophys. Acta - Mol. Basis Dis., 1502(1): 139144 (2000).

11. Bolton, J. L., Trush, M. A., Penning, T. M., Dryhurst, G. \& Monks, T. J., Role of quinones in toxicology. Chem. Res. Toxicol., 13(3): 135-160 (2000).

12. Alam, M. N., Bristi, N. J. \& Rafiquzzaman, M., Review on in vivo and in vitro methods evaluation of antioxidant activity. Saudi Pharm. J., 21(2): 143-152 (2013).

13. Bernhoft, A., Siem, H., Bjertness, E., Meltzer, M., Flaten, T. \& Holmsen, E., Bioactive compounds in plants-benefits and 
risks for man and animals. The Norwegian Academy of Science and Letters, Oslo, (2010).

14. Ishrat, T., Hoda, M. N., Khan, M. B., Yousuf, S., Ahmad, M., Khan, M. M., Ahmad, A., et al., Amelioration of cognitive deficits and neurodegeneration by curcumin in rat model of sporadic dementia of Alzheimer's type (SDAT). Eur. Neuropsychopharmacol., 19(9): 636-647 (2009).

15. Srivastava, J. K., Shankar, E. \& Gupta, S., Chamomile: a herbal medicine of the past with a bright future. Mol. Med. Rep., 3(6): 895-901 (2010).

16. Jaradat, N. A., Al-Masri, M., Zaid, A. N., Hussein, F., Al-Rimawi, F., Mokh, A. A., Mokh, J. A., et al., Phytochemical, antimicrobial and antioxidant preliminary screening of a traditional Palestinian medicinal plant, Ononis pubescens L. Eur. J. Integr. Med., 14: 46-51 (2017).

17. Vyas, N., Tailang, M., Gavatia, N. P. \& Gupta, B. K., Antioxidant potential of Psidium guajava Linn. Int. J. PharmTech Res., 2(1): 417-419 (2010).

18. Ojezele, O. J., Ojezele, M. O. \& Adeosun, A. M., Comparative phytochemistry and antioxidant activities of water and ethanol extract of Annona muricata Linn Leaf, seed and fruit. Adv. Biol. Res. (Rennes)., 10(4): 230-235 (2016).

19. Yefrida., Suryani, H., Alif, A., Azis, H. \& Efdi, M., Modification of phenanthroline method to determine antioxidant content in tropical fruits methanolic extract. Res. J. Chem. Environ., 22(4): 28-35 (2018).

20. Szydłowska-Czerniak, A., Dianoczki, C., Recseg, K., Karlovits, G. \& Szłyk, E., Determination of antioxidant capacities of vegetable oils by ferric-ion spectrophotometric methods. Talanta, 76(4): 899-905 (2008).

21. Molyneux, P., The use of the stable free radical diphenylpicrylhydrazyl (DPPH) for estimating antioxidant activity. Songklanakarin J. sci. technol, 26(2): 211-219 (2004).

22. Horwitz, W., AOAC guidelines for single laboratory validation of chemical methods for dietary supplements and botanicals. Gaithersburg, MD, USA: AOAC International, (2002).

23. Guilford, J., Fundamental statistics in psychology and education, 3e éd. (1956).

24. Chew, K. K., Khoo, M. Z., Ng, S. Y., Thoo, Y. Y., Aida, W. W. M. \& Ho, C. W., Effect of ethanol concentration, extraction time and extraction temperature on the recovery of phenolic compounds and antioxidant capacity of Orthosiphon stamineus extracts. Int. Food Res. J., 18(4): 1427 (2011).

25. Naczk, M. \& Shahidi, F., Extraction and analysis of phenolics in food. J. Chromatogr. A, 1054(1): 95-111 (2004). 